\title{
Merajut Motif Batik Solo Sebagai Solusi Guna Mengatasi Pengangguran Lulusan SMA/SMK di Desa Ngargoyoso Kabupaten Karanganyar Akibat Covid-19
}

\author{
${ }^{1 *}$ Dicky Heru Saputra, ${ }^{1}$ Indriyanti Feronika, ${ }^{1}$ Sonya Agustina Dewi Rahayu, ${ }^{2}$ Alfina Damayanti, ${ }^{2}$ Shafira \\ Allayda Hernany Eddy
}

\begin{abstract}
${ }^{1}$ Fakultas Geografi, Universitas Muhammadiyah Surakarta, Indonesia
${ }^{2}$ Fakultas Psikologi, Universitas Muhammadiyah Surakarta, Indonesia

*Penulis korespondensi, email: dickyherusaputra@gmail.com
\end{abstract}

(Received: 31 August 2021/Accepted: 27 January 2022/Published: 31 January 2022)

\begin{abstract}
Abstrak
Krisis ekonomi global yang terjadi akibat pandemi Covid-19 turut memicu timbulnya berbagai macam permasalahan sosial masyarakat luas. Kabupaten Karanganyar menjadi salah satu kabupaten yang merasakan dampak turunnya pendapatan akibat Covid-19. Salah satunya terjadi di Desa Ngargoyoso, Kecamatan Ngargoyoso. Mayoritas masyarakat Desa Ngargoyoso lulusan dari bangku pendidikan tingkat SMA/SMK, lebih cenderung memilih untuk bekerja. Menurut data Badan Pusat Statistik, dibandingkan dengan Jumlah Angkatan kerja yang mengalami kenaikan, Pastisipasi Angkatan Kerja justru mengalami penurunan sebesar 0,15\% yang di dominasi oleh Lulusan SMK/SMA. Masyarakat Desa Ngargoyoso yang lebih banyak menggantungkan hidupnya dari sektor agraris lokal, kini mengalami kerugian akibat penurunan di beberapa komoditas karena wabah Covid-19 yang meningkat, khususnya komoditas unggulan (sayuran). Penghasilan yang semakin menurun, serta sumber daya manusia yang terus meningkat membuat diperlukannya sebuah wadah yang dapat mengedukasi masyarakat untuk mengembangkan potensi lain yang dapat dilakukan oleh masyarakat selama pandemi. Pelatihan Merajut dapat dinilai menjadi kegiatan yang efektif dan efisien, karena pengerjaan yang mudah dan dapat dilakukan dimanapun dan kapanpun. Motif Batik Solo dalam proses pelatihan ini diharap juga dapat menjadi ciri khas produk hasil rajutan dari Desa Ngargoyoso. Selain itu, pelatihan ini juga dapat sekaligus untuk mengurangi tingkat stress, dan depresi akibat tekanan yang dirasakan selama pandemi.
\end{abstract}

Kata Kunci: Desa Ngargoyoso, Merajut, Motif Batik Solo

\begin{abstract}
Global economic crisis that occurred due in this pandemic, it also triggers various kinds of social problems in wide community. Karanganyar Regency is one of the districts that has felt the impact of the decline in income due to Covid-19. One of them happened in Ngargoyoso Village, Ngargoyoso District. The majority, public of the Ngargoyoso Village graduates from high school/vocational level education, more likely to choose to work. The people of Ngargoyoso Village, who mostly depend on the local agrarian sector, are now experiencing losses due to a decline in several commodities due to the increasing Covid-19 outbreak, especially superior commodities (vegetables). Declining incomes, as well as increasing human resources make the need for a forum that can educate the public to develop other potentials that can be done by the community during the pandemic. Knitting training can be considered to be an effective and efficient activity, because the work is easy and can be done anywhere and anytime. Solo Batik Motif in the training process can also become a characteristic of knitted products from Ngargoyoso Village. In addition, this training can also simultaneously reduce stress levels and depression due to the pressure felt during the pandemic. In the current pandemic era, many teenagers want to do other activities by further developing creativity in their productive age, which can be done at any time
\end{abstract}


Keywords : Ngargoyoso Village, Knitting, Batik Solo Motif

\section{Pendahuluan}

Pandemi Covid-19 yang mempengaruhi setiap lapisan masyarakat, salah satunya adalah sektor perkonomian, baik ekonomi global maupun domestik. Selain memicu krisis ekonomi, masa pandemi juga memicu adanya tingkat stress dan depresi, hingga resiko bunuh diri dikarenakan rendahnya pendapatan, meningkatnya pengangguran di tengah masyarakat (Winurini, 2020). Selain itu, dibatasinya mobilitas ataupun pergerakan seperti dari kebijakan PSBB maupun social distancing juga menyebabkan tingkat perubahan sosial di masyarakat (Sayuti, 2020). Perubahan mobilitas maupun sosial masyarakat juga berdampak terhadap perubahan ekonomi masyarakat. Menurut riset kementrian keuangan membuktikan, turunnya perekonomian terjadi akibat rendahnya daya beli dan pengurangan tenaga kerja (Pakpahan 2020). Hal tersebut sesuai dengan bukti dari Kementerian Ketenagakerjaan per 20 April 2020 mencatat sebanyak 2.084.593 pekerja dari 116.370 perusahaan dirumahkan dan terkena Pemutusan Hubungan Kerja (LIPI, 2020).

Badan Pusat Statistik menyebutkan bahwa Jumlah angkatan kerja per Februari 2020 mencapai angka 137,91 juta mengalami kenaikan sebesar 1,73 juta orang. Naiknya jumlah angkatan kerja ini berbanding terbalik terhadap tingkat partisipasi angkatan kerja yang turun 0,15 $\%$. Penurunan ini dipengaruhi oleh bertambahnya angka pengangguran dengan jumlah 60 ribu orang, didominasi oleh lulusan sekolah menengah kejuruan dengan persentase sebesar 8,49 persen. (Badan Pusat Statistik, 2020).

Kabupaten Karanganyar menjadi salah satu kabupaten yang merasakan dampak turunnya pendapatan akibat Covid-19. Hal ini serta merta juga menyebabkan pendapatan daerah yang awalnya dianggarkan sejumlah Rp. 2.225.308.095.000, akhirnya mengalami perubahan pada tahun 2020, turun sebesar 5,83\% menjadi Rp.129.654.491.000 (Diskominfo Kabupaten Karanganyar, 2020). Desa Ngargoyoso menjadi salah satu desa di Kabupaten Karanganyar yang masuk ke dalam kategori daerah yang terdampak Covid-19 yang cukup tinggi dari segi ekonomi. Desa Ngargoyoso, Kecamatan Ngargoyoso, Kabupaten Karanganyar merupakan sebuah desa yang memiliki topografi perbukitan atau lereng, secara spesifik desa ini terletak di dataran tinggi dekat kaki Gunung Lawu. Sebagian besar daerah Desa Ngargoyoso merupakan wilayah pertanian serta perkebunan, sehingga penduduk Desa Ngargoyoso bermata pencaharian sebagai petani.

Kondisi Desa Ngargoyoso tidaklah termasuk dalam garis kemiskinan namun juga tidak pada garis masyarakat yang memiliki penghasilan yang tinggi. Baik sebelum ataupun saat pandemi perekonomian masyarakat hanya bergantung pada sektor pertanian, dimana hasil tani yang pada masa pandemi ini memiliki harga yang sangat rendah bahkan sampai tidak laku terjual.

Desa Ngargoyoso pada tahun 2020 terdiri dari 1221 Kepala Keluarga atau KK (Pemerintah Desa Ngargoyoso, 2020). Dimana dari jumlah tersebut sebagian besar atau sekitar 2.778 penduduk bermata pencaharian sebagai petani. Rata-rata penghasilan masyarakat perharinya adalah Rp 25.000-40.000, sehingga dapat diakumulasi pendapatan per bulan sekitar Rp $750.000-1.200 .000$. Terlebih lagi di era pandemi saat ini, sektor pertanian mengalami penurunan yang sangat signifikan. Terutama dalam segi harga, sayur-sayuran yang semakin menurun, seperti harga mentimun dari harga Rp 3.000,00 menjadi Rp 800. Bukan hanya itu saja, sayur-sayuran lain seperti sawi yang sebelum pandemi mencapai harga Rp 2.500 per kilogram, sekarang hanya berkisar Rp 1.000 per kilogram. Bahkan hasil tani seperti singkong, lengkuas, kunyit pun juga mengalami penurunan hingga $65 \%$. Hal tersebut mengakibatkan banyak masyarakat yang resah hingga sering mengeluh bahkan sampai mengalami tekanan psikis, karena banyaknya kebutuhan yang semakin meningkat tidak diimbangi dengan kesejahteraan perekonomian yang ada.

Eksistensi pendidikan berkaitan erat dengan pertumbuhan ekonomi, sering ditemukan bahwa pendidikan tidak terlepas dari masalah ekonomi, baik secara langsung maupun tidak langsung (Faridah, 2020). Orientasi sebagian besar orang tua di masyarakat Desa Ngargoyoso 
adalah cepat untuk bekerja tanpa diimbangi dengan kualitas pendidikan yang memadai. Semakin meningkatnya lulusan SMA/SMK yang tidak melanjutkan ke jenjang perguruan tinggi di tahun 2020 ini menjadi salah satu fenomena yang sangat disayangkan. Karena rendahnya perekonomian masyarakat di era pandemi Covid-19 mengakibatkan banyak remaja usia produktif yang tidak dapat melanjutkan pendidikan ke jenjang yang lebih tinggi.

Menurut United Nations transisi demografi yang terjadi pada beberapa dekade terakhir di Indonesia akan membuka peluang bagi Indonesia untuk menikmati bonus demografi pada periode tahun 2020-2030 (Maryati, 2015). Banyaknya remaja yang memiliki kreativitas, ketrampilan, pengetahuan dan penguasaan teknologi, diharapkan dapat segera menyiapkan adanya bonus demografi yang akan datang, sehingga remaja di Desa Ngargoyoso mampu bersaing ketika bonus demografi.

Terdapat kurang lebih 437 warga yang berusia produktif kerja dengan mayoritas berada di rentan usia sekitar 18-26 tahun, dan sisanya berusia 26 tahun keatas (Pemerintah Desa Ngargoyoso, 2020). Dimana sebagian besar dari jumlah tersebut merupakan remaja lulusan SMA/SMK yang belum memiliki pekerjaan, dikarenakan adanya pandemi Covid-19. Selain sektor kesehatan, pandemi Covid-19 berdampak terhadap sektor ekonomi khususnya keberlangsungan pekerjaan dan pendapatan. Adanya tumpang tindih antara sumber daya alam dan sumber daya manusia menjadikan turunnya perekonomian di Desa Ngargoyoso dimana banyak usia produktif remaja yang jenuh akan sistem kerja petani yang monoton dan cenderung hanya mengandalkan pada hasil pasca panen seperti penjualan bahan mentah. Perlu adanya inovasi baru bagi para remaja untuk meningkatkan kreativitas, memanfaatkan waktu luang khususnya di masa pandemi, serta menjadi suatu keterampilan yang digunakan sebagai bekal usaha untuk peningkatan ekonomi setempat. Pelatihan ini bertujuan untuk mengembangkan kreativitas merajut motif batik solo bagi remaja Karang Taruna Desa Ngargoyoso. Kedua, untuk memperkenalkan kearifan lokal budaya dari motif batik Kota Solo yang di kombinasikan dengan karya rajutan. Ketiga, mengurangi tekanan psikis masyarakat akibat adanya dampak Covid-19 terhadap ekonomi.

\section{Metode}

Pelaksanaan kegiatan pelatihan diawali dengan tahap persiapan yang terlebih dahulu mendatangi mitra karang taruna guna meminta ijin sekaligus memaparkan tujuan dan maksud dilakukan kegiatan pengabdian. Kemudian, dilanjut dengan koordinasi serta melakukan survey untuk memilih beberapa titik lokasi yang akan dijadikan tempat pelatihan merajut. Pelatihan dilakukan 2 metode, yakni secara langsung menggunakan metode Mobile Training Unit dengan melaksanakan pelatihan di lingkungan rumah warga setempat, serta menggunakan metode Online Training untuk memberikan pemahaman lebih mengenai teori dasar serta produk yang akan dihasilkan dari pelatihan merajut. Adapun keseluruhan kegiatan dilaksanakan sebagai berikut:

a. Pembelian alat dan bahan

Pertama adalah menyiapkan alat dan bahan yang diperlukan dalam program pelatihan, seperti melakukan pembelian bahan baku di pasar baik pasar offline maupun pasar online.

b. Pembuatan Materi pelatihan

Pembuatan materi yang dibagi menjadi 2 jenis, yaitu dengan media cetak (buku pedoman) dan media virtual (video tutorial).

c. Pelaksanaan Pelatihan Merajut

Pelaksanan Kegiatan dibagi menjadi 4 tahap dengan sosialisasi mengenai kegiatan yang dapat dilakukan pada masa pandemi. Selanjutnya, Pembentukan kader sekaligus pembuatan grup WhatsApp, dimana dalam pembentukan kader ini diambil 4 remaja karang taruna. Tahap berikutnya adalah pelatihan khusus untuk para kader dan Kegiatan 
yang terakhir yakni pendampingan untuk melakukan koordinasi dengan pihak kader terkait pelatihan.

d. Evaluasi kegiatan

Menyediakan platform berupa google form, serta evaluasi dengan grup WhatsApp yang nantinya akan lebih efektif untuk melakukan evaluasi di setiap minggunya.

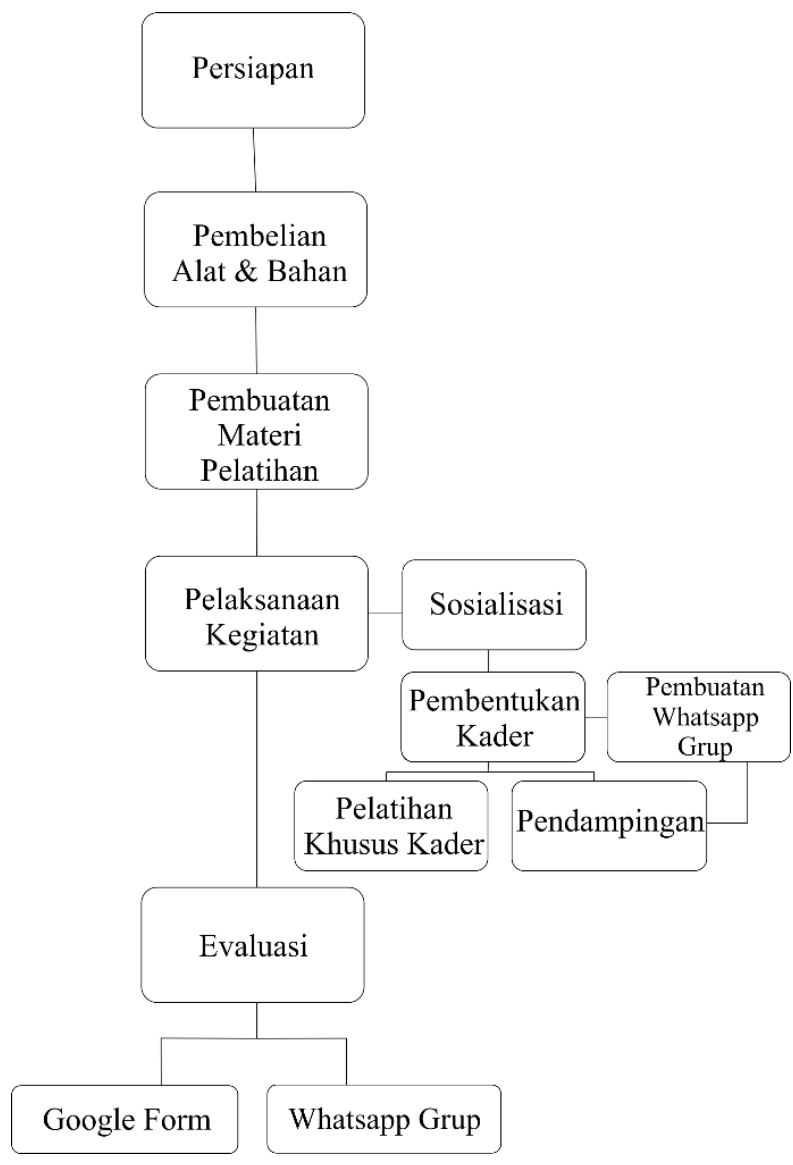

Gambar 1. Diagram Alir Program Pelatihan Merajut

\section{Hasil dan Pembahasan}

Berdasarkan hasil sosialisasi program kegiatan pengabdian yaitu pelatihan merajut motif batik solo di Desa Ngargoyoso dimana pihak karang taruna yang menjadi mitra dalam kegiatan tersebut yang memiliki 60 anggota, 31 laki-laki dan 29 perempuan. Sebanyak 23 anggota terdaftar serta mengikuti pelatihan yang semuanya merupakan anggota karang taruna putri, hal tersebut dikarenakan hasil pendataan dari mitra yang minat sekaligus memiliki antusias yang lebih tinggi. 23 anggota tersebut dibagi menjadi 2 kelompok pelatihan dengan 4 kader. Kader merupakan anggota pilihan yang ditunjuk untuk menjadi Koordinator Pelatihan Merajut Motif Batik Solo. Seperti pada Gambar 2, dimana pembekalan serta pendampingan kader dilakukan secara online dengan menggunakan platform Zoom Meeting untuk memberikan gambaran kegiatan maupun perkenalan yang dapat memperlancar pelatihan. 


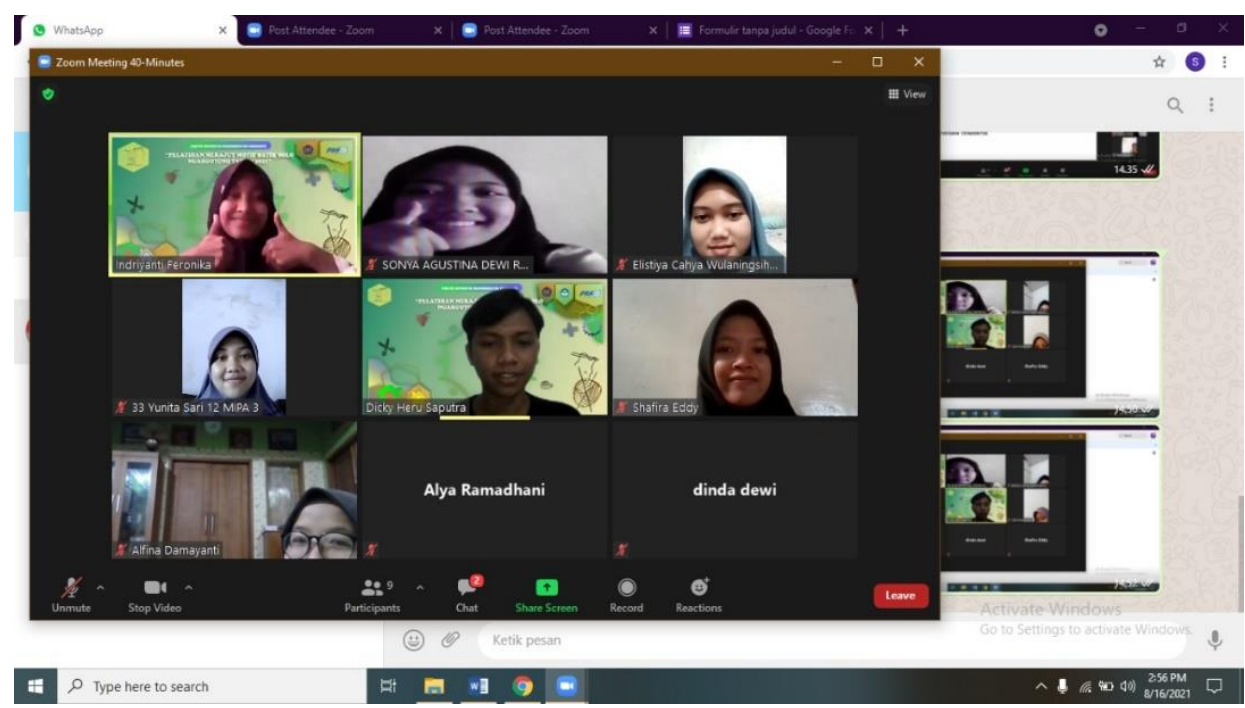

Gambar 2. Dokumentasi Pembekalan Kader

Pelatihan dilakukan secara online maupun offline, kegiatan online dilakukan saat pembekalan, memberikan meteri secara teori kepada kader. Desa Ngargoyoso merupakan desa yang berada di wilayah perbukitan tepatnya di bawah lereng Gunung Lawu, sehingga masalah keterbatasan jaringan sering dikeluhkan oleh masyarakat setempat. Sehingga kegiatan online hanya diikuti oleh kader beserta beberapa peserta pelatihan lainnya. Kegiatan penyampaian materi secara teori seputar merajut dapat dilihat pada Gambar 3.
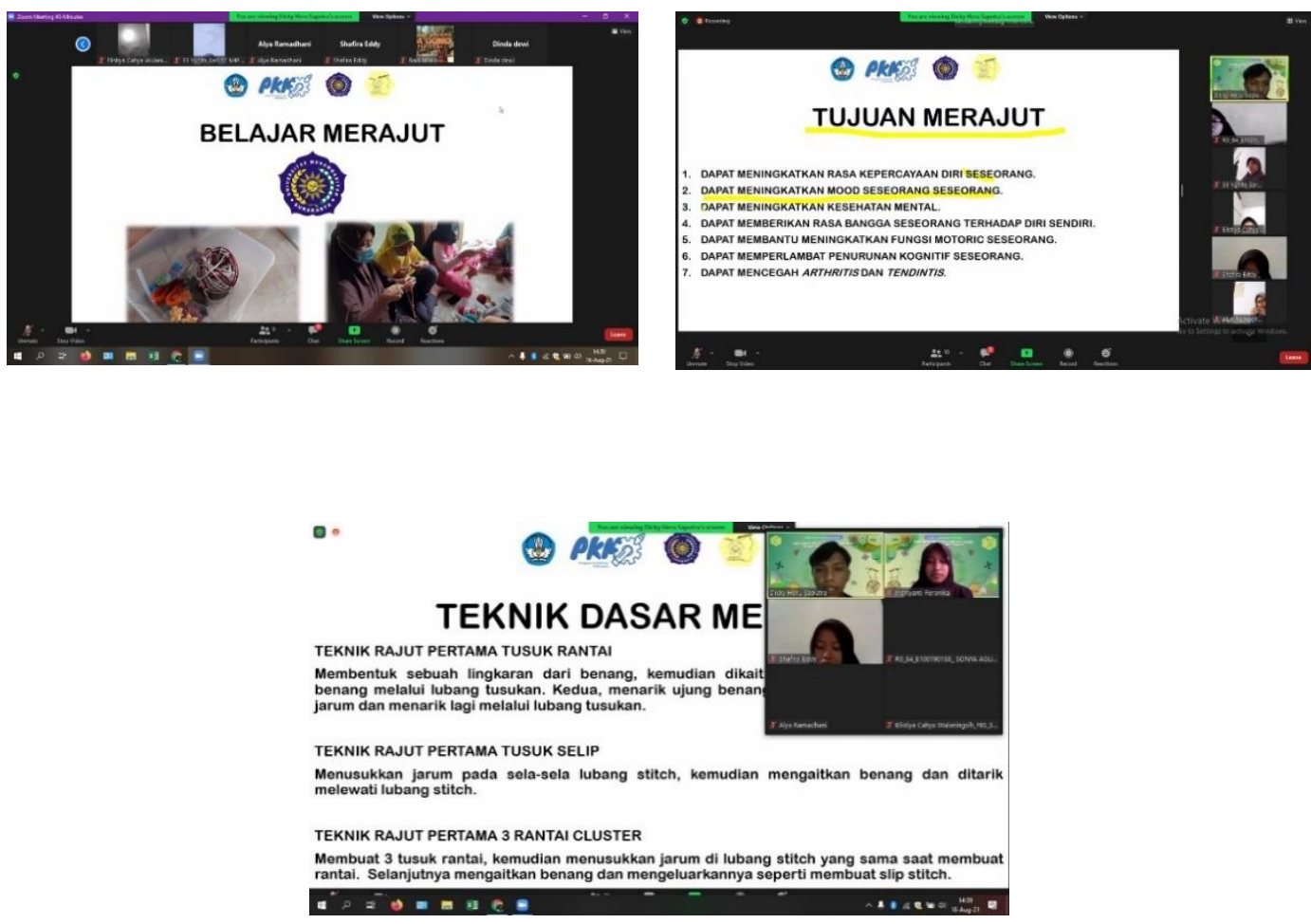

Gambar 3. Penyampaian Materi Seputar Merajut 
Sebelum pelatihan dilakukan secara offline, maka pengenalan mengenai materi merajut juga dikenalkan secara online. Materi yang disampaikan yaitu meliputi pengertian merajut, manfaat dan tujuan merajut utamanya di era pandemi, pengenalan alat dan bahan yang harus disiapkan, teknik maupun pola merajut, hingga nilai estetik dan daya jual hasil rajut. Era milenial memiliki kreativitas sangat penting untuk menciptakan inovasi baru, salah satunya adalah pelatihan merajut. Merajut merupakan sebuah kreativitas yang tepat untuk pemuda karena dapat dilakukan dengan waktu dan lokasi yang fleksibel, sehingga pemuda lulusan SMA/SMK yang belum memiliki pekerjaan mampu memanfaatkan waktu dengan kegiatan yang produktif serta menghasilkan suatu produk yang memiliki nilai jual. Selain itu untuk alat dan bahannya juga cukup mudah untuk dijangkau, seperti benang wol atau benang katun, hakpen/jarum rajut, jarum tumpul, gunting, metlin, jarum jahit, dan manik-manik sebagai bahan pelengkap.

Tidak semua anggota pelatihan memiliki pengetahuan seputar merajut tersebut, sehingga pemberian materi secara teori dinilai penting sebelum melakukan pelatihan secara langsung. Hal tersebut bertujuan untuk meningkatkan antusias serta rasa keingintahuan peserta pelatihan. Penyampaian materi secara online ini berlangsung selama kurang lebih 90 menit, dimana untuk beberapa materi dilihat pada Gambar 4 yaitu pokok materi yang disampaikan, yaitu materi pengertian merajut, tujuan merajut, alat dan bahan merajut, serta teknik dasar dari merajut.

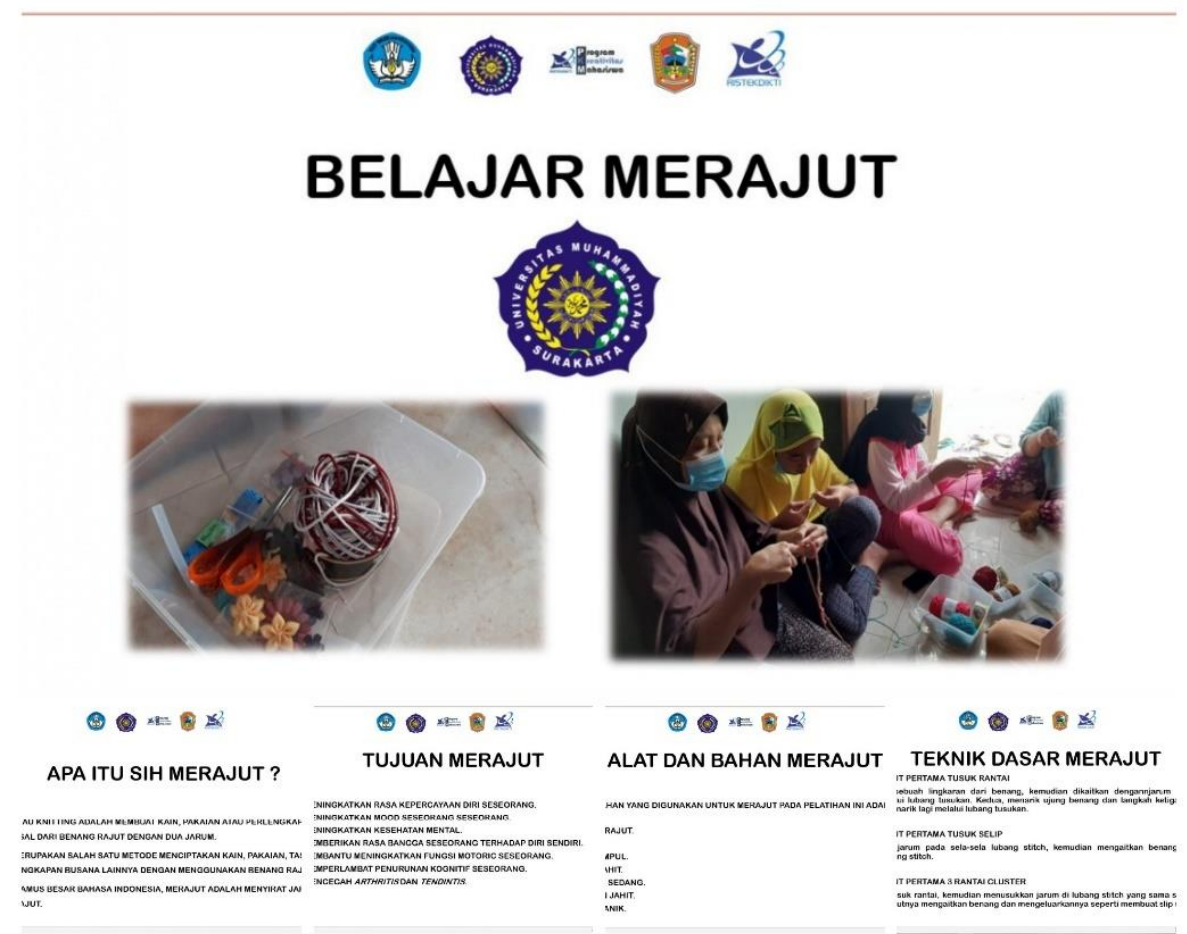

Gambar 4. Beberapa Slide Materi Pelatihan

Melalui adanya penyampaian materi secara teori membuat peserta memiliki antusias yang tinggi, dilihat dari jumlah hadir pelatihan secara offline yang dilakukan menjadi dua kelompok. Meskipun pelatihan ini dilakukan di tengah pandemi, pelatihan secara offline pertama diikuti sebanyak 15 orang beserta 4 kader, dimana untuk 8 peserta lainnya mengikuti pelatihan secara offline di hari kedua. Pelatihan pertama terlebih dahulu dikenalkan dengan alat dan bahan yang dibantu oleh kader, kemudian dari kelompok tersebut dibagi kembali menjadi dua orang dengan satu pembimbing, agar lebih efektif dan sekaligus menerapkan protokol kesehatan. Selama kegiatan berlangsung peserta memiliki antusias yang cukup baik di setiap pertemuan. Dapat dilihat pada Gambar 5 dimana merupakan proses pelatihan dengan dua kelompok. 

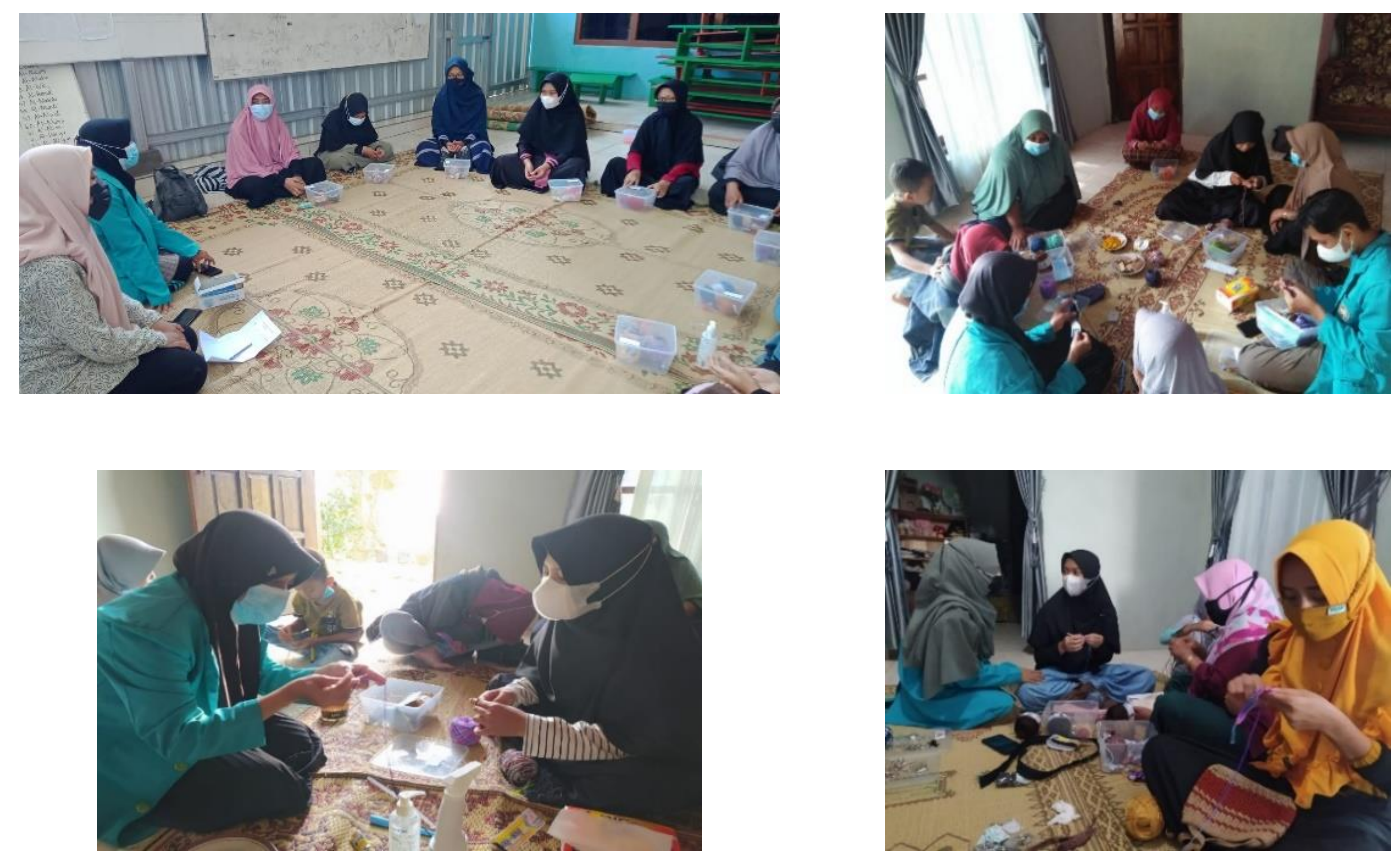

Gambar 5. Pelatihan Merajut Secara Offline

Setiap pertemuan pelatihan secara offline memiliki materi yang berbeda-beda, pertemuan pertama adalah pelatihan teknik dasar yaitu pembuatan pola rantai. Pola rantai ini merupakan dasar dari proses merajut, selain pola merajut di pelatihan pertama peserta juga membuat pola single crochet atau tusuk tunggal hingga pola double crochet atau tusuk ganda Melalui Pelatihan yang telah dilakukan baik daring maupun luring, dapat meningkatkan pengetahuan mitra. Kondisi ini diketahui dari semakin berkembangnya teknik atau metode yang digunakan untuk menghasilkan produk rajutan yang sesuai.

Meningkatnya pengetahuan mitra ini juga tercemin dari produk rajutan yang menghasilkan beberapa variasi bentuk, pola, dan jenis khususnya motif Batik Solo yang dapat menjadi ciri khas tersendiri. Bermula dari pola dasar yakni pola rantai, single crochet, dan double crochet yang dapat dilihat pada Gambar 6, mitra mampu mengembangkan menjadi sebuah barang layak pakai yang mampu bersaing di pasaran.

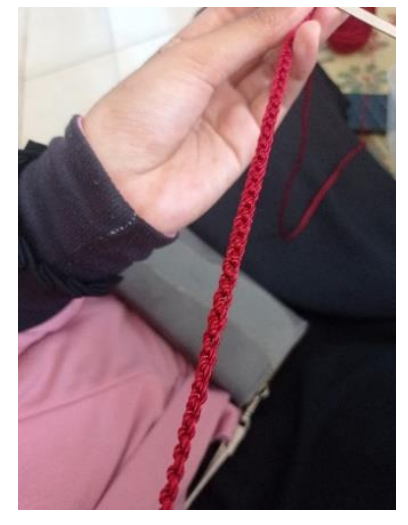

(Pola Rantai)

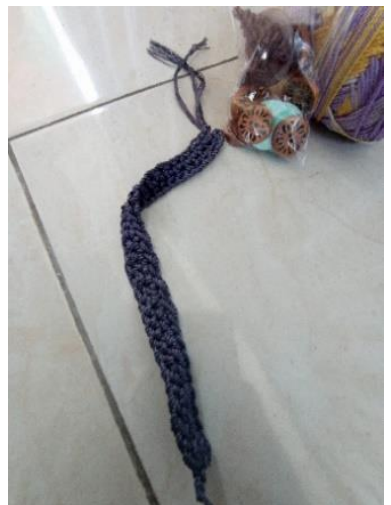

(Single Crochet/tusuk tunggal)

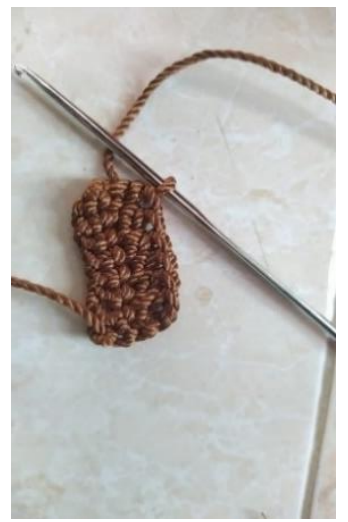

(Double Crochet/tusuk ganda)

Gambar 6. Hasil Pola Dasar 
Selain itu di sela-sela hari pelatihan offline, peserta juga dibina melalui grup WhatsApp dimana melalui media tersebut dapat mengetahui perkembangan peserta selama pelatihan mandiri dengan materi video yang sudah diberikan. Peserta juga memiliki antusias yang baik saat pendampingan melalui grup WhatsApp, dapat dilihat respon peserta pada Gambar 7. Akan tetapi pada beberapa pertemuan kemudian beberapa peserta cenderung pasif ketika di grup WhatsApp sehingga hal tersebut juga menjadi kendala selama pelatihan, dikarenakan sulitnya pemantauan progress kemajuan mitra ketika pelatihan dilakukan secara mandiri. Kendala ini menyebabkan terhambatnya beberapa pembelian bahan habis pakai karena komunikasi yang kurang. Akhirnya untuk mengatasi kondisi tersebut adalah melakukan inisiatif pemantauan ketika pelatihan online, dan ditemukan kendala lain seperti gangguan sinyal yang juga terkadang masih terjadi pada peserta. Meskipun demikian pelaksanaan pelatihan dan pendampingan tetap dapat dilaksanakan dengan baik, diimbangi dengan lebih digiatkan pada saat pelatihan offline dengan membentuk kelompok saat pelatihan dimana dalam satu kelompok didampingi oleh salah satu kader dan tim pengabdian.
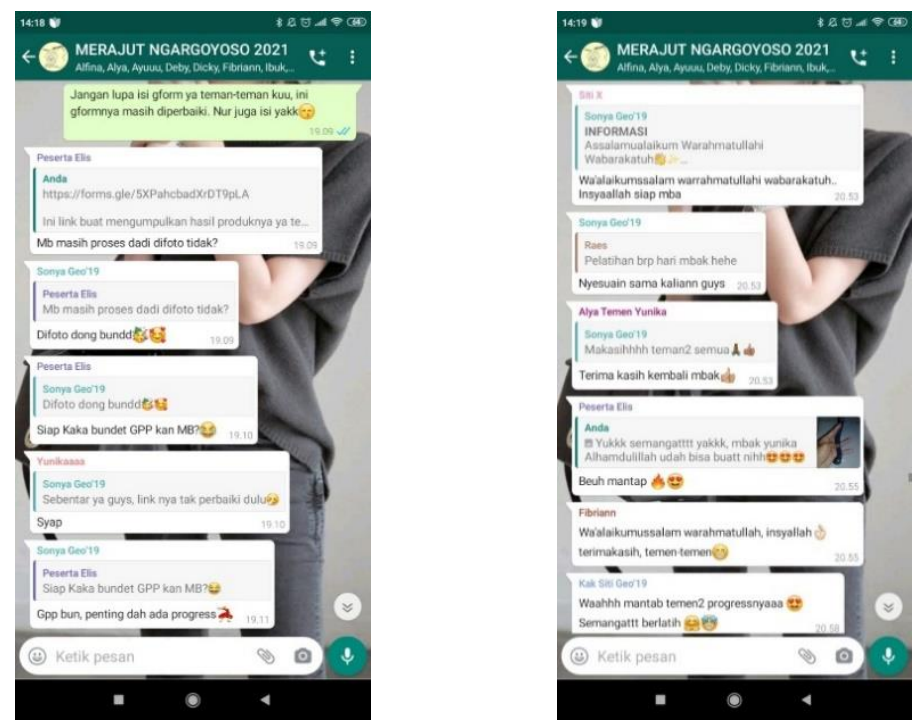

Gambar 7. Pendampingan Online Melalui WhatsApp Grup

Setelah pertemuan pertama membuat pola dasar, maka dipertemuan berikutnya adalah membuat pola dengan tujuan pembuatan suatu produk. Sebagian besar peserta memilih membuat dompet, tas dan strap masker. Pelatihan kedua ini masih pada pola kreasi lainnya, kemudian untuk pelatihan ketiga mulai memasuki pola Batik Solo. Baik dari pemilihan warna maupun pola belajar pembuatan tas dan strap masker, mayoritas peserta berhasil menghasilkan suatu produk, dari 23 anggota menghasilkan sebanyak 11 produk final atau sudah sepenuhnya jadi, sedangkan untuk 12 produk lainnya masih dalam proses penyelesaian tahap akhir seperti pemasangan manik-manik, resleting, kain keras, maupun penggait selempang tas. Beberapa hasil produk yang sudah jadi dapat dilihat pada Gambar 8 yaitu hasil kreasi motif batik dan kreasi lainnya. Adapun beberapa motif yang telah selsai menjadi suatu hasil produk layak jual adalah strap masker dengan dua jenis yaitu motif bunga panjang dan motif batik pendek, selain itu terdapat beberapa jenis tas maupun dompet dengan motif yang berbeda, diantaranya yaitu tas slempang motif batik kerang, tas slempang motif batik garis, tas slempang motif batik kawung, tas slempang motif polos, dan dompet motif polos.

Hasil produk tersebut dihasilkan oleh peserta di saat pelatihan maupun pengerjaan mandiri di luar waktu pelatihan. Peserta sebagian besar lebih interaktif dengan mencoba beberapa model dengan kreasi yang berada di tutorial YouTube, sehingga beberapa peserta dapat membuat lebih dari satu produk baik dalam model ukuran besar maupun kecil. 

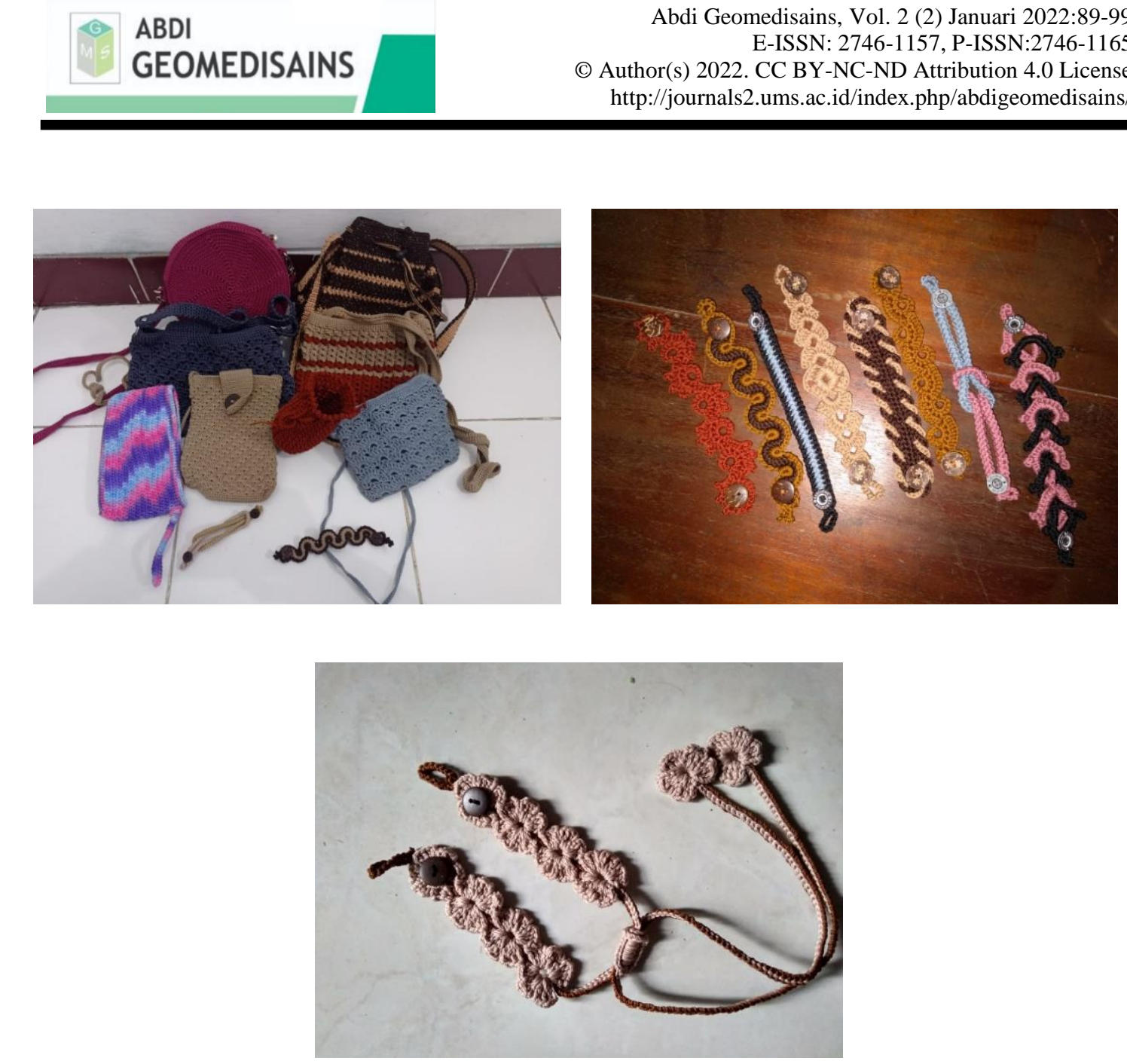

Gambar 8. Hasil Produk Rajutan

Evaluasi dan pemantauan mengenai progress selama pelatihan dilakukan pada akhir pelatihan. Progres pelatihan merajut dinilai berdasarkan jumlah peserta yang mampu menguasai setiap pola yang diajarkan, seberapa besar persen progress pelatihan dapat dilihat pada Gambar 9, dimana pola dasar single crochet yang memiliki progress sebesar $14 \%$, dan double crochet $17 \%, \mathrm{HDC}$ atau half double crochet sebesar 15\%, pola TC atau trable crochet sebesar 13\%, pola atau teknik FPDC (front point double crochet) sebesar 9\%, pola BPDC (back point double crochet) sebesar $14 \%$, dan progress hasil jadi suatu produk sebesar $14 \%$.

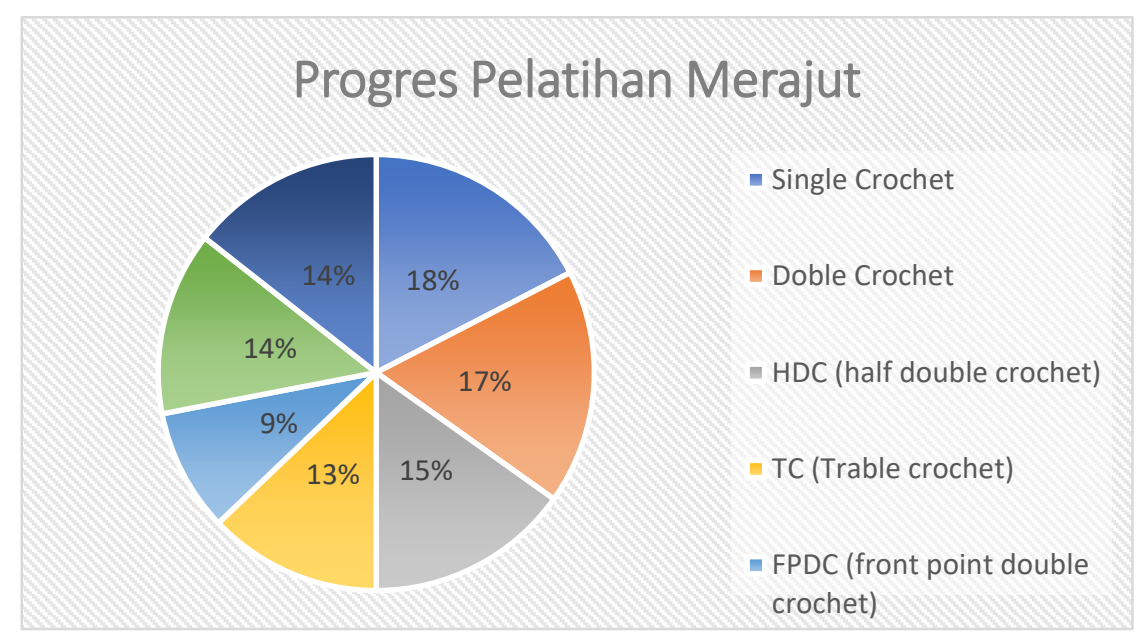

Gambar 9. Progress Pelatihan Merajut Berdasarkan Hasil Pola Dasar 
Produk rajutan yang telah dihasilkan memiliki nilai estetik yang berdaya jual, sehingga diharapkan pemuda karang taruna mampu melajutkan kreativitas merajut supaya dapat memberdayakan masyarakat sekitar serta mampu menjadi wadah untuk penjualan hasil rajutan sebagai inovasi peningkatan perkonomian, serta mengurangi pengangguran.

\section{Simpulan}

Melalui kegiatan pelatihan merajut motif batik solo yang telah dilakukan kepada mitra karang taruna Desa Ngargoyoso, pengetahuan serta keterampilan para remaja bertambah, khususnya kerajinan tangan berbentuk rajutan. Dalam kurun waktu 1 bulan pelatihan ini sudah menghasilkan produk jadi sebanyak 12 produk, diantaranya yaitu strap masker panjang motif bunga, strap pendek motif batik dan motif bunga, tas slempang motif batik kerang, tas slempang motif batik garis, tas slempang motif batik kawung, tas slemang motif polos, dan dompet motif polos. Antusiasme dari peserta sangat baik, terutama saat pelatihan offline berlangsung peserta sangat aktif bertanya serta meminta kader maupun tim pengabdian untuk membantu secara langsung, hal tersebut juga dilihat dari antusias di media online walaupun memang banyak peserta yang terkendala jaringan tetapi peserta tetap berinisitif untuk aktif walaupun di beberapa saat kemudian setelah mendapat jaringan. Pelatihan yang dilakukan kurang lebih selama 1 bulan ini, dapat dikatakan berhasil karena remaja karang taruna lulusan SMA/SMK mampu untuk membuat sebuah karya atau produk yang memiliki nilai jual yang tinggi. Dimana hal tersebut mengindikasikan bahwa pengetahuan dan keterampilan masyarakat sebagai solusi untuk mengurangi masalah pengangguran sekaligus menjadi upaya dalam mengisi waktu selama pandemi telah meningkat.

\section{Persantunan}

Terimakasih penulis ucapkan kepada Karang Taruna Satria Desa Ngargoyoso yang telah mengijinkan serta memperkenankan kami untuk mengadakan Pelatihan Merajut Motif Batik Solo sebagai upaya untuk mengatasi pengangguran akibat Covid-19, terutama untuk kawula muda remaja lulusan SMA/SMK.

\section{Referensi}

Badan Pusat Statistik. (2020). Tingkat Pengangguran Terbuka (TPT) sebesar 4,99 persen. Diakses dari https://www.bps.go.id.html [16 Agustus 2021]

Diskominfo Kabupaten Karanganyar. (2020). Nota Keuangan dan RAPBD Kabupaten Karanganyar TA 2020. Diakses dari https://www.karanganyarkab.go.id. [16 Agustus 2021]

Faridah. (2020). Pengaruh Ekonomi Terhadap Pendidikan Anak Di Masa Pandemi Covid-19. Diakses dari https://www.stit-alkifayahriau.ac.id. [26 Agustus 2021]

Lembaga Ilmu Pengetahuan Indonesia. (2020). Survei Dampak Darurat Virus Corona terhadap Tenaga Kerja Indonesia. Diakses dari http://lipi.go.id. [26 November 2020]

Maryati, S. (2015). Dinamika Pengangguran Terdidik: Tantangan Menuju Bonus Demografi di Indonesia. Journal of Economic and Economic Education, 3(2), 124-136.

Pakpahan, A K. (2020). Covid-19 dan Implikasi Bagi Usaha Mikro Kecil dan Menengah. Jurnal Ilmiah Hubungan Internasional, 38(70), 59-64.

Pemerintah Desa Ngargoyoso. (2020). Profil Desa Ngargoyoso: Daftar Isi Tingkat Perkembangan Desa/Kelurahan Edisi ke-5. Karanganyar: Dinas Pemberdayaan Masyarakat dan Desa Kabupaten Karanganyar.

Winurini, S. (2020). Permasalahan Kesehatan Mental Akibat Pandemi Covid- 19. Jurnal Bidang Kesejahteraan Sosial, 12(15), 13-18.

Sayuti, R., H dan Siti Aisyah. (2020). Dampak Pandemi Covid-19 Terhadap Ekonomi Masyarakat di Nusa Tenggara Barat. Jurnal Jurnal Riset Sosiologi Progresif Aktual, 2(2), 134-150. 


\section{(c) (i) () $\Theta$}

(c) 2022 by the authors. Submitted for possible open access publication under the terms and conditions of the Creative Commons Attribution (CC-BY-NC-ND) license (http://creativecommons.org/licenses/by/4.0/) 